\title{
Together or Apart? Integration Processes of Italian Immigrants in the Republic of Nobles
}

There has been quite a lot written on activities of the Italians in the Polish-Lithuanian Commonwealth. We have many facts about the lives and achievements of many outstanding figures, especially artists (architects and builders, musicians, people of theatre) as well as merchants and enterprisers. And despite all that, the phenomenon of Italian immigration to the territory of the Polish-Lithuanian state seems to have been insufficiently examined - both from the perspective of Italian motivations and extent of fulfilment of their life plans related to Poland, and from the perspective of consequences of the Italian presence for the old Polish society - both in the sphere of culture and politics, and economy. Thus, a relative advancement of studies is accompanied by an ignorance (generally, although not always, being a consequence of scarcity of sources) in fundamental questions - a number of Italian immigrants and chronology of their arrival to Poland, their professional structure, and their territorial settlement, especially outside big cities. There is a need for further studies exploring the goals set by individuals belonging to this very diverse community, and assessing the extent to which they were fulfilled.

First and foremost, however, it is the scale of impact those Italian arrivals had on various factions and communities of the old-Polish society. The whole picture of this process will be very difficult to reconstruct. Before I attempt to do so, I would like to present a few remarks and doubts about the level of their integration and possible group solidarity that characterised the Italian minority in the Commonwealth. Thus, it 
will be interesting for us to see whether the Italians (understood as the inhabitants of Italy) in emigration were tied by all-Italian (not to say "nationwide") bonds or whether their patriotism and sense of community were of local character and were limited to a concrete small independent state or city in the Italian Peninsula? A concurrent question about the relations within the Italian society will refer to the mutual relationship of people living in different regions of Italy, who in a foreign territory could coexist and cooperate, but could also compete and get into conflicts.

In the second part of my reflections I will present my observations about the nature of relationship between Italian arrivals and Polish-Lithuanian hosts, trying to find an explanation for this especially intense Italian immigration to the territory of the Commonwealth.

In general, the most important spheres of Italian activity in the Commonwealth of the $16^{\text {th }}-17^{\text {th }}$ century are well-known. Instead of listing them here, I will propose - as an introduction to the main body of my reflections - to have a look at a fragment of Italian community seen through the prism of two different block of diplomatic correspondence; the correspondence published in print, but probably still insufficiently appreciated by historians. Thus, it will be "the Italian world on the Vistula River" in miniature; a small fragment of the reality the representativeness of which cannot be proven but cannot be excluded either.

The "Italian world" understood in this way is a probing attempt referring to the Italian characters who appear in the correspondence which was carried on between the Italians staying in Poland with their partners in the homeland. It will be interesting to see the group of Italians (but only those who at that particular period of time were in Poland) mentioned - in any context - in Italian letters written from Poland; in one word, we are interested in the world of Italian, personal references, seen through the prism of letters written from Poland.

Our research sample is based on two collections of letters; the collections which - as for our source publications - have been published quite recently. The first one is the Correspondence of Sebastiano and Valerio Montelupi (1576-1609), published by Danuta Quirini-Popławska (1986), the second one is a collection of letters written by Niccolò Siri from Cracow and Warsaw in $1642-1645$, prepared for publication by Tessa 
Capponi-Borawska (1993). The addressees and receivers of a majority of these letters were living in Florence; in the case of the Montelupi it were great dukes of Tuscany, Francesco I and Ferdinando I de' Medici, and their influential First Secretary of State, Belisario Vinta, while Siri's letters were written mainly to Vinta's counterpart of the 1640s, Giovanni Battista Gondi. And although it is impossible to evidence either the representativeness or completeness of these collections of letters, they form the editorial whole and as such they could be, as it seems, analysed also from this angle.

"The Italians in Poland" mentioned in Montelupi's letters turned out to be quite a small group of 29 persons, but surprisingly pronounced and easy to characterise. Considering the fact that the letters were written by Italian merchants who settled permanently in Cracow, we are not surprise to find that the most numerous group of people mentioned in the correspondence were their professional partners and colleagues as well as subordinate employees. In total, the group numbered fifteen people (eight plus seven); among the commercial partners there were well-known figures in the world of business: Florentine merchant trading mainly in silk Marco Bartoli, two members of the famous banking family Carlo and Bernardo Soderini, and their Cracow partners - Lorenzo Nelli and Filippo Talducci, as well as Giulio del Chiaro cooperating with the Nurnberg firm of the Torrigiani or Tuscan commercial agents interested in Polish grain - Neri Giraldi and Riccardo Riccardi. Almost as often there were mentioned people employed by the Montelupi eider in connection with their commissions and tasks to fulfil or in the contexts of quarrels and disputes (long-lasting and troublesome!) which they kept up with their employers. This community was mainly of Tuscan origins.

Apart from this group whose presence in the letters is explained by professional activities of their authors, there is another clear set of people, that is easy to distinguish, made up of nine persons: papal diplomats who stayed in Poland at various times. Such a large number was possible and resulted from the fact that the analysed letters were written throughout the period longer than twenty five years, but the size and relative completeness of the group of nuncios mentioned in the Montelupi's letters make us think. Since we deal here not only with successive papal diplomats who resided in Poland for several years (Alberto Bolognetti, Girolamo Bovio [de' Buoi], Germanico Malaspina), but also with those who were sent with single legations only; and this was both the first rank of diplomats 
for whom their office or intense public activity had brought common respect (Jesuit Antonio Possevino - a mediator between King Bathory and Ivan the Terrible, Cardinal legate Ippolito Aldobrandini, whom we owe the peace treaty - called in the literature on the subject the treaty of Bytom and Będzin - between King Sigismund III and the emperor in 1589, Cardinal Enrico Caetani, who during his over one-year-long formal legation was very anxious for the Poles to join the anti-Turkish league), and the people from the second rank of the papal diplomacy, but very important for us today - as the author of preserved written accounts or other source texts (Alfonso Visconti, Benedetto Mandina, Alessandro Cumuleo or Caetani’s secretary Bonifazio Vanozzi).

Apart from this stricte professional sphere and the group of nuncios, there is one more group, the least numerous, because in fact made up of four persons. ${ }^{1}$ It included, in the order of their appearance in the letters: Annibale Rosselli from Calabria, a professor of Cracow Academy, superior of the Franciscans who in 1585 visited the Polish Franciscan provinces, Simone Genga, a military architect in the service of King Stephen Bathory, and at the same time a Tuscan resident, who was invested with diplomatic functions at the Vienna court, in Hungary and in Poland, Luigi Bevilacqua, a Tuscan envoy who pay a courtesy visit in Poland in 1609, and finally Alessandro Cilli, a musician and intellectual, active at the court of King Sigismund III Vasa, later the director of the royal band, also from Tuscany and also fulfilling diplomatic functions.

Except for Rosselli, whose person of titled ecclesiastical and intellectual aroused understandable interest that did not need any additional motifs, what the three remaining persons had in common was their Tuscan origin and diplomatic activity, which in the case of Luigi Bevilacqua meant an official representation of the Florentine court. ${ }^{2}$ Of Tuscan origin was also the great majority of people classified as commercial partners and collaborators of the authors of the analysed letters, while carrying out a diplomatic function was common for the four people making up the most expressive group of papal diplomats.

Thus, the above review of the people of the Italian provenance mentioned in the Montelupi's letters could be the basis for at least two assertions. One suggests that the Italians staying in the territory of the

1 The fifth person was a certain Alberto Machiavelli, but we know nothing about him.

2 W. Tygielski, Dyplomacja - informacja - propaganda. Podróż Luigiego Bevilacqua, posta toskańskiego na dwory europejskie w 1609 r., Warsaw, 2000, passim. 
Commonwealth were prone to stay isolated within their own group, determined by a common origin either from a single geographic region or a state in the territory of Italy. In a word - "a small homeland" rather than all-Italian structure and network of relations. The second conclusion coming to mind emphasises the importance of diplomacy as the sphere of Italian activity, and within it - a special role of the papal nunciature - as the institution which not only aroused general interest among the Italians staying abroad but also could form a focus of their integration and a permanent point of reference, making it easier for this diversified group of people to self-identify.

A reading of the second block of letters has led us to similar conclusions. It is a smaller set but much more uniform - the letters were written during a much shorter period of a few years (and not a few dozen), and by one person only, in addition also employed in the diplomatic service. Let us remind: Niccolò Siri, a Tuscan resident, in the 1640s wrote letters to the First Secretary of State, Giovanni Battista Gondi.

In Siri's published letters there appear twelve figures interesting to us. The territorial provenance of a majority of them is difficult to establish, but three of them seem to confirm the importance of Tuscan bonds. Angelo Incontri aroused Siri's interest for he came to Poland engaged in some vague business matters and brought with him, among other things, presents (five mules) from the grand duke for the Polish monarch; an another Tuscan, Carlo Costa, who came quite unexpectedly to Cracow, was described by the author as "molto mio Padrone," and even more original present which was transported by this traveller to Florence also was described in a letter; ${ }^{3}$ finally, Francesco Maria Simoni, a merchant active in Warsaw at that time who had difficulties in settling accounts and payments with his local partners, could count - as it is evident from the letters - on the protection of the grand duke and an intervention with the king probably rescued him from his problems.

Almost all the remaining persons (with one exception only) could be included to the group of people associated with diplomacy. Apart from two papal nuncios, Mario Filonardi and Giovanni de Torres, they were associated with - which seems to be both characteristic and significant - the diplomacy of the Commonwealth. The famous Capuchin Father Valerio (Massimiliano) Magni, multiple representative of the papal

3 „[...] una mezza zampa di ungia della Gran Bestia”, N. Siri, Lettere da Cracovia e Varsavia (1642-1645), ed. by T. Capponi-Borawska, Warsaw, 1993, p. 42. 
diplomacy - first in Vienna, next in Warsaw - would then represent the Polish king in Rome; Domenico Roncalli, royal secretary and canon of Warmia, was in turn a representative of the Polish court first in France, and then in Rome; another secretary of King Wladislaus IV Vasa, Lodovico Fantoni, was preparing himself to a diplomatic journey to the imperial court. There is also another person who could be added to the group of those three most famous Italians active in the Polish diplomatic service, Francesco Bibboni, a resident of King Wladislaus in Vienna and Madrid; it is right to mention here that it was mentioned above Angelo Incontri who competed with Bibboni for this diplomatic post. Diplomats of Italian states are represented within this group only by the Venetian Ambassador Giovanni Tiepolo and his colleague Girolamo Castellani, whom Siri had a chance to get to know better when they travelled together through the Commonwealth and who later was an envoy of King Wladislaus to Vienna. It is evident, then, that almost all the people mentioned above had diplomatic inclinations.

Let us repeat it once more: "the Italians in Poland" seen through the prism of Siri's letters were mostly diplomats (which could be explained by the character of the source), in their majority providing their professional services to the Polish king. A relatively large share of space is occupied also by papal envoys, especially Mario Filonardi who was in a sharp conflict with the Polish king and had to - as the only nuncio in history - leave his post and the territory of the Polish-Lithuanian Commonwealth at the explicit request of the monarch. This remarkable episode in the relationship between the papacy and Commonwealth was sure to attract the attention of outside observers, as is evident from the letters of the Tuscan resident.

Although the scarcity of sources and a probing character of the analysis do not authorise us to draw any far-reaching conclusions, it is possible to say that - like in the case of the Montelupi's letters - among the characteristics of people mentioned in Siri's letters their "small homeland" (the Grand Duchy of Tuscany) seems to have occupied a fairly important place as the basis for their bonds and collective self-identification.

This should not surprise us, however, since for the majority of Italians migrating to the Commonwealth a focus for their national self-identification was most probably their home city or political centre in the case of a larger structure of state character. People were aware of the fact, also in Poland: 
Że oni informują rzemieślnika wszędzie

Tak Weneta, jako też Peneemczyka [Piemontczyka],

Lukczyka, Bonona i też Florentczyka;

Żeby zacnych dawniejszych sobie zaniechali

Materyj, a podlejsze dla was wymyślali $[\ldots]^{4^{*}}$

as Gabriel Krasiński wrote in his anti-Italian satire Lament of the Polish Crown (Lament Korony Polskiej, ca. 1657), a fragment of which we quote here not for its heavy style, but because of its exceptionally good level of geographical knowledge of the Italian Peninsula and Italian internal diversity. ${ }^{5}$

Such identification with the homeland seems to be quite normal and rather lasting. In the Pamiętnik Historyczno-Politycznego, an Enlightenment magazine published in 1782-1792, in a special cycle devoted to the contemporary Italy we could read: "What a great difference between a certain Venetian and Roman, between Genoese and Milanese, between Florentine and Neapolitan!' It followed from further detailed reflections that, among other things, the inhabitants of Piedmont were distinguished by their "industry, activity and laboriousness" and in this regard they "surpass all other nations in Italy," that the Florentines "exceed other Italians in boastfulness," and in the Republic of Lucca "greater equality is seen between the citizens and such freedom for all which is in vain to be looked for in all Italy." ${ }^{\prime} \mathrm{A}$ vitality of such types of division, at least in Europe, is testified by the changes of the last two centuries.

In any case, the political fragmentation and deep differences between particular regions of the Italian Peninsula in the early modern period were an unquestionable fact which has to be taken into consideration also when we study Italian emigration. This was usually done in historiography, especially the older one, which - as much as it was made possible by

$4^{*}$ That they inform a craftsman everywhere,

Both a Venetian and Piedmontese,

Luccane, Bonone and also Florentine;

That they should give up older worthy

Matters, and invented inferior ones for us [...].

5 G. Krasiński, Taniec Rzeczypospolitej Polskiej, ed. by M. Korolko, Warsaw, 1996, p. 123.

6 Z. Libera, 'Obraz Włoch w oczach "Pamiętnika Historyczno-Politycznego"', in: Filologia e letteratura nei paesi slavi. Studi in onore di Sante Graciotti, ed. by G. Brogi Bercoff, M. Capaldo, J. Jerkov Capaldo, and E. Sgambati, Rome, 1990, pp. 229, 233, 235, 237. 
available sources - attached a lot of importance to the place of origin of Italian arrivals, trying to put them in order according to their "small homelands" in Italy. We can observe such a research attitude starting with Louis Fournier, who by the end of the $19^{\text {th }}$ century wrote about the Florentines in Poland (Rita Mazzei could be regarded as his present-day continuator, who is interested in merchant activity of the Luccanes), ${ }^{7}$ then going to Stanisław Windakiewicz (who divided the history of the Commonwealth into phases of Florentine influences and then Venetian ones), and Jan Ptaśnik, to whom a geographical and cultural attribution of Italian arrivals was very important. A different attitude is represented by historians of culture (Roman Pollak, Claude Backvis, Tadeusz Ulewicz), inclined to treat "Italian influences" as a uniform phenomenon.

What is significant from our perspective are manifestations of all-Italian nationwide awareness, based on the sense of cultural unity of Italy (the language - despite deep dialectal differences - was already performing this function), and maybe on the sense of community of heritage, as well as geopolitical interests. It is probable that a Turkish threat accelerated such changes in awareness in the Italian Peninsula, although on the other hand the Spanish domination in the north (Milan) and in the south (the Kingdom of Naples) was not favourable to the process of Italian integration. The question about the integral role played by the papacy remains open (it seems to be underestimated in the literature on the subject), as well as the significance of main political and civilisation centres, such as Venice and Florence, and the political structures which they created for the acceleration of nation-building processes in the scale of the whole Italian Peninsula.

Did the early modern Italian emigration, including the emigration to the Polish-Lithuanian Commonwealth, play any role in this process?

Bonds and conflicts within the Italian community Here, a main subject of our reflections are mutual relations within the Italian community. It is necessary to pose the question whether these Italians created a community whose members identified themselves and were able to form a sense of collective solidarity or rather their thinking and awareness were individualised and they regarded their fellow

7 See: L. Foumier, Les Florentins en Pologne, Lyon, 1893; R. Mazzei, Traffici e uomini d"affari italiani in Polonia nel seicento, Milan, 1983; cf. also, S. Windakiewicz, Padwa. Studyum z dziejów cywilizacji polskiej, Cracow, 1891, pp. 12-13. 
countrymen as rivals, although we can only dream of an explicit answer. Apart from an evident conflict of interests between the Italian arrivals, there is another unknown, that is an extent of national integration of the early modern inhabitants of the Italian Peninsula together with a cultural and language distance between the inhabitants of particular Italian states and regions. Another thing, that in a foreign territory a tendency to the integration within a community could have been much larger.

\section{Bonds}

Indeed, that must have been the case, especially that Italian commercial operations in the $16^{\text {th }}$ and $17^{\text {th }}$ centuries were conducted at a really large scale. Successive and effective operations of large firms required a large number of partners and commercial agents scattered throughout a large territory - efficient, loyal and trustworthy: their Italian origin was almost a rule. ${ }^{8}$

There were also strong bonds between the members of other social and professional groups coexisting within the Italian community. The Venetian envoy Alvise Foscarini who had just came to Tyniec near Cracow, in his letter to the Venetian doge Leonardo Donato, written on 17 June 1606, described the last section of his route from Vienna to Cracow. He emphasised that - because of special dangers of travelling along the roads - he left Vienna accompanied by an escort of thirty horse, in large part made up of Venetians, or in any case of the subjects of the Venetian doge who in this way wanted to pay him due respect. ${ }^{9}$ In his later route the Venetian diplomat was supported and protected by the 150-strong cavalry unit commanded by a certain Signor Basti. For some reasons the envoy included a warm praise of this commander in his correspondence which in this fragment became a kind of recommendation letter.

Manifestations of solidarity referring to the community of national character could be observed on a voyage not necessarily to the distant

8 See: R. Mazzei, Itinera Mercatorum. Circolazione di uomini e beni nell"Europa centroorientale: 1550-1650, Lucca, 1999, pp. 93-94, with an interesting list of commercial agents of Pietro Antonio de Nobili, operating "in partibus Alemanniae, Poloniae et Ungariae".

9 "[...] compresi il Clarissimo Signor Camillo Trivisan, et alcuni sudditi della Serenità Vostra [...] li quali in questa occasione non hanno tralasciato alcun segno, dove habbino potuto far conoscer la loro devotione nella persona di me suo rappresentante", Fontes Rerum Polonicarum e tabulario Reipublicae Venetae, ed. by A. Cieszkowski, Series 2, Fasc. 1: Litterae Ambaxatorum Venetorum apud Regem Poloniae ab anno 1574 usque ad annum 1606, Venice, 1892-1902, p. 270. 
Commonwealth. The former functionary of the apostolic nunciature Giacomo Fantuzzi (auditor, that is a court official), after ending his mission was returning in the mid- $17^{\text {th }}$ century from Poland to Rome, and visiting Europe, described such an episode during a stay in Amsterdam. "I have also experienced - wrote the Italian traveller who suffered some health problems in the Netherlands - a caring assistance from Sirs Giovanni Andrea and Ottavio Tencini, Italian merchants, the Florentines at whose place I was always hearing Mass. I was directed to them by Sir Gratta of Danzig." 10

A clear network of contacts with the common denominator of Italian origin seems to appear here. An Italian-Catholic who does not feel secure in the Protestant world looks for support, points of reference, possibilities to practice freely their religious faith. He finds them at Italian merchants; they are from Florence (Tuscany), he is from Ravenna/ Bologna (Emilia-Romagna) - this is not far away, and any possible differences surely evident over there, in Italy, are of no importance here in the distant Netherlands. Fantuzzi could find his fellow countrymen in Amsterdam owing to the directions given by Francesco Gratta from Danzig (because it is almost sure that it was him), the organiser of the post office on behalf of the Polish royal court, which soon would to include the whole territory of Royal Prussia, Courland and Livonia. Gratta was from Lucca (also not far away, in today's Tuscany, although earlier Lucca was for decades the leading rival of Florence); he appeared in Poland several years earlier, probably in the entourage of Queen Marie-Louise Gonzaga. Evidently, Fantuzzi got in touch with him when he was travelling through Danzig, even though he did not describe it in the relevant fragment of his diary. The postmaster had contacts in the whole region, he knew addresses; Fantuzzi was interested in them but most probably he used only some of them; but the whole episode seems to testify to the existence of strong bonds and group solidarity between the Italians scattered throughout the whole Europe, at least in the context of travel, its hardships and risks.

Did the situation of the Italians in Poland stimulate analogous behaviours and attitudes?

Let us begin with a certain political episode. When in 1575 in Florence a conspiracy was discovered against the Medici, a part of its leaders

10 G. Fantuzzi, Diariusz podróży po Europie (1652), transl. and ed. by W. Tygielski, Warsaw, 1990, p. 112. 
decided to run for their lives. At least one of the conspirators, a certain Pietro Ridolfi, went via Venice to Cracow, and from there - after several months in this city - left for Germany. The Cracow episode of Ridolfi is interesting to us because of his contacts there: among the people entertaining him in the Polish capital were Tommaso Lenzi and Urbano Ubaldini della Ripa, the merchants from Florence and at the same time the leading figures among the members of Cracow's Italian community. ${ }^{11}$ Evidently, the Italian defector had no problems in establishing where and from whom he could find support in the faraway city of Cracow. A network of Italian (or maybe only Tuscan?) solidarity included also Poland! Precisely so: Italian or Tuscan?

Being aware of the fact that we still remain in the sphere of hypotheses, let us consider situational variants which could suggest some correct generalisations. It could be accepted, for example, that in the initial period of Italian immigration to Poland, when the number of Italians in the Commonwealth was small, the need for group integration and mutual assistance was stronger than rivalry and competition. With the lapse of time and the increased number of Italian newcomers in the Commonwealth, however, this tendency could have been reversed. In this version, group solidarity dominated at the beginning and then - with the narrowing of the possibilities of action - it would have been replaced with rivalry; thus, first the harmony, then conflicts.

But a different scenario was also possible, which seems to us more probable, to wit that initially (until the mid $-16^{\text {th }}$ century?) internal divisions between the Italians who had come to Poland were much more evident, because at that time - in the initial phase - they competed between themselves for a new space of activity and that resulting conflicts were gradually less and less sharp, and differences between the representatives of various regions of Italy were increasingly obliterated (throughout the $17^{\text {th }}$ century?), for their adaptation to new conditions united them.

Bonds were created by common work. Actions undertaken by the first generation of Italian builders who gathered at the court of King Sigismund the Old and transferred Renaissance solutions to the Polish soil probably required group solidarity in order to successfully - regardless of the protection of the king - overcome a local conservatism and technical difficulties. We can imagine that the Tuscans cooperating with Berrecci at

11 Mazzei, Itinera Mercatorum, p. 339. 
the building of the Sigismund Chapel, Giovanni Cini of Siena, Antonio da Fiesole (then from the neighbourhood of Florence), and a pupil of Andrea Sansovino, Niccolò de Castiglione and Guglielmo called the Florentine, made such a well-tuned and harmoniously cooperating, and for this reason effective team. Let us add that there is evidence for bonds of friendship between Cini and Berrecci. Because when our Sienese, constantly seeking new challenges, was leaving Cracow in 1529, he bequeathed his local fortune to Berrecci and a certain Bernardo Romano, an architect of Wola Justowska. ${ }^{12}$

And here are some other - diverse by assumption - examples of common functioning and mutual experiences. Rich Florentine merchants, Luca and Giulio del Pace, in their Cracow company employed the Florentines (Pier-Maria Ceffini, Filippo Talducci, Antonio Viviani); we also know that they conducted their business activities with a Vienna company of Giovanni Rogazzi, and a Florentine one - of Antonio Nella, and also with a bank of Sebastiano Montelupi. Next events, both in the private and professional sphere, would evidence in this context the significance of Italian community. When in 1581-1584 a lawsuit was taking place between Cracow merchants and cloth-makers (an object at issue was the permissible scale and range of cloth trade), the del Pace family was represented by the Italian solicitor Giovanni Thedaldi; when, in turn, they had a lawsuit against Antonio Viviani due to their mutual financial settlements (1607), the matter was settled by the arbitration court in which served the Italian entrepreneurs form the Polish market: Urbano Ubaldini della Ripa of Lvov, Francesco Tellari, Michel Angiolo Leri and Giovanni Pietro Cernezzi. ${ }^{13}$

Thanks to financial difficulties which in 1648 troubled the Lvov's merchant and entrepreneur Filippo Ducci we can get to know a list of his creditors at that time. The list is strongly Italianized, for it includes mainly the Italian manufacturers of silk cloth: Castel-Moro, Cortino, Bertholi, Bolzani, there are also the names of local merchants: Orsetti and Bandinella. An inventory of Ducci's personal property, in turn, compiled after the death of his wife in 1675 also includes numerous names of Italian merchants as his creditors (Ghiberti, Savioli, Pestalozzi, Uberti); in both cases this testifies explicitly although indirectly to close

12 M. and S. Cercha, Pomniki Krakowa, Cracow and Warsaw, 1904, vol. 2, p. 172.

13 See: J. Ptaśnik, 'Z dziejów kultury wtoskiego Krakowa', Rocznik Krakowski, 9, 1907, pp. 96-97. 
commercial contacts with fellow countrymen. ${ }^{14}$ In this case, however, like in the next ones, the Italian origin of the interested parties was treated in a general way, without indicating their "small homeland."

A certain Giacopo Izabelius, who apparently served meritoriously in the wars with Moscow and at the end of the $16^{\text {th }}$ century strove for the ennoblement or, in fact, for the formal renovation of his noble title which had been enjoyed in Venice by his father Lorenzo, took advantage not only of the support of the nobility of Vitsyebsk (Vitebsk) who evidently knew his merits, but - to prove his noble origin - also of the testimonies of his two compatriots staying at that time in Poland: the royal court physician Niccolò Bucelli, and the court historiographer Alessandro Guagnini (known as Gwagnin in Poland) of Verona; nota bene, the both witnesses had gained the Polish certificates of nobility - Bucella only some time earlier, in 1589, Guagnini already in $1571 .^{15}$

In the second half of the $17^{\text {th }}$ century Angelo Maria Bandinella acted occasionally as an agent authorised with full powers, also in financial matters, of Tito Livio Burattini. Bandinella was initially a postmaster who then expanded his services (which certainly have turned out to be profitable) to encompass the whole country. ${ }^{16}$ Yet, affairs and financial transactions in which Burattini participated, a great entrepreneur and controversial leaseholder of mints, belonged to the most serious ones, thus such an authorisation had its weight. It is no problem to list the names of his numerous Italian collaborators, constantly present in the most important spheres of his activities - starting with his political partners, influential at the court, such as Geronimo Pinocci and Sebastiano Cefali, then going through Paolo Del Buono, a director of the imperial mint, with whom Burattini in 1656 had meetings in Vienna, where they planned their operations in the Polish monetary market, or Buono Del Buono, the full brother of Paolo, a courtier of Kings John Casimir

14 W. Łoziński, Patrycyat i mieszczaństwo lwowskie w XVI i XVII w., Lvov, 1892, pp. 187-89.

15 Album armorum nobilium Regni Poloniae, XV-XVIII saec. Herby nobilitacji i indygenatów, $X V$-XVIII $w$., introduction and ed. by. B. Trelińska, Lublin, 2001, pp. 173, $214,267$.

16 In the 1660s he was already described as "mastro generale delle poste", A. Favaro, 'Intorno alla vita ed ai lavori di Tito Livio Burattini, fisico agordino del secolo XVII', Memorie del Reale Istituto Veneto di Scienze, Lettere ed Arti, 25, 1896, 8, p. 25, note 1, see also p. 100, were the fact of correspondence between Burattini and Cefali, who in the summer of 1665 was in Florence, is verified. 
and Michał Korybut, and ending with a certain Fakineti, a minter in the mint of Bydgoszcz. ${ }^{17}$

Geronimo Pinocci himself, when he opened a mint in Lvov in 1656, he located his minting factory in a townhouse belonging to the Bandinelli, at the market square, and made Lorenzo Bandinelli his closest collaborator in this apparently profitable enterprise; two years later, when Pinocci was sent with diplomatic missions to England and Holland, Bandinelli was included in his retinue, which I regard as yet another evidence of the durability of the bonds within this community.

And a final motif. Niccolò Siri, the already quoted Florentine diplomat residing from 1642 on in Cracow, in January 1645 decided to move to Warsaw because of the proximity of the royal court and an approaching session of the Sejm. While making his decision to move, he was aware of the fact (which is evidenced in his letters) that in Warsaw he would join in a strong Italian community gathered around the royal court, which included: Lodovico Fantoni, Valeriano Magni, Francesco Bibboni and Domenico Roncalli. This perspective must have seemed quite attractive and alluring to Siri. We also know that in 1647 his efforts at the court were supported by Francesco Magni, Valeriano's brother.

It was the apostolic nunciature that remained a constant, at least potentially, point of reference, or maybe even an integrating factor, for the Italian presence in the Commonwealth. I do not want to say that the papal nuncio represented the whole Italy (as was done by the ambassador of the Italian Republic). Certainly, the permanent state of political fragmentation in the Italian Peninsula together with political conflicts between particular entities excluded such his role. What is more, we could not be able to prove that a Tuscan or Venetian staying temporarily in Poland would be ready to regard the nuncio as his representative.

Yet it seems, on the other hand, that from the perspective of many Italians, especially those residing at the Polish court or staying in its orbit, the permanent presence of a diplomatic post of the Italian origin could have been important and comforting. An additional factor was the international reputation of this diplomatic structure and the comparability of its role and authority in the scale of the whole Catholic Europe. Contacts with the nuncio residing in the country and his milieu were

17 Diariusz sejmu koronacyjnego 1669 roku, ed. by K. Przyboś and M. Ferenc, Cracow, 2004, p. 33. 
a constant and obvious item on the agenda of any foreign diplomat, especially when he was the envoy of a Catholic monarch.

The French legation, the mediation of which led in 1635 to the Polish-Swedish treaty of Stuhmsdorf (Sztumska Wieś), did not break the rule. The envoy Claudes de Mesmes, count d'Avaux, had numerous contacts with Nuncio Onorato Visconti, also by letters. Interestingly, the member of the envoy's retinue responsible for the preparation and expedition of those letters Karol Ogier seized an opportunity and addressed a letter "to the most honoured and reverend Apostolic Nuncio at the Polish court with the request for permission to read some books."18 As an orthodox Catholic with a vivid mind and intellectual inclinations he was seeking to obtain dispensation for private lectures. It is obvious that professional contacts with the local nuncio made things simpler.

A gradual unification of the community of Italian immigrants and obliteration of the divisions which had been more pronounced before could be evidenced by the appearance in sources of the term "nazione italiana", clearly used by them to describe the whole Italian group. When after the death of Queen Cecilia Renata of Austria (24 March 1644) the question of remarriage of King Wladislaus IV Vasa became open, one of the candidates was Anna de' Medici. Or at least this was how this question was seen by the Florentine resident Niccolò Siri, who - as we remember - had been already residing in Cracow for a longer time and corresponded regularly with the secretary of Grand Duke Ferdinando II, Giovanni Battista Gondi, and at that time was ready to play the role of mediator in the marriage negotiations. In his confident letter to Gondi, written from Cracow on 28 May 1644, Siri then recommended his own service, emphasising his excellent contacts with the local nobility in which he was allegedly surpassing all other Italians in the Commonwealth. ${ }^{19}$ In the letter he suggested that a potential negotiator should be appointed from among the group of "nazione italiana". Clearly, it was broadly constructed but relatively unambiguous concept. And although the context of the matter indicates that it was about someone who was related to Tuscany and the court of the Medici, the term "nazione italiana"

18 K. Ogier, Dziennik podróży do Polski, 1635-1636, transl. by E. Jędrkiewicz, ed. by W. Czapliński and I. Fabiani-Madeyska, Part I, Gdańsk, 1950, p. 351.

19 Siri asked Gondio "se verrà in trattato, come spero, questo negotio" that he recommended his services to the Grand Duchy and assured that both of them would be pleased with his services "[...] essendo qua da questa nobiltà ben voluto [...] più di nessun altro della nazione italiana”, Siri, Lettere da Cracovia, p. 124. 
proved to be sufficient to indicate the group of possible candidates. Thus, we would be justified in assuming that both the letter's author and its addressee understood it more broadly - as a group of "Italian-speaking" persons or people of "Italian origin."

A similar indication is present in a previous letter of Siri, written from Warsaw on 11 August 1643, also addressed to Giovanni Battista Gondi. This time Siri was writing about King Wladislaus IV's plans to send two envoys: one to France with condolences upon the death of French monarch, and the second one to Denmark to negotiate a possible anti-Swedish alliance. The Danish mission was entrusted to Henryk Denhoff, and the second one - to the royal secretary Domenico Roncalli, described by Siri as "nostro italiano", who was to go to Paris and spend there some time as an official Polish resident. ${ }^{20}$ Thus, we again deal with the signalised sense of community of universal all-Italian character. It turned out that the Italian origin in a foreign territory was not only a clearly distinguishing feature and a constructive element of mutual identification but also could serve as the foundation of solidarity among the Italians based on the common origins and basic elements of cultural self-identification.

The need of such identification was evidenced by the establishment in Cracow of a specific Italian institution in the form of confraternity at the Franciscan church and cloister. It became the centre around which the Italian community concentrated - starting from the $16^{\text {th }}$ century obviously interested, at least initially, in emphasising its own autonomy. In the first half of the century, already under Queen Bona Sforza, there was an Italian Chapel founded at this church which then functioned for many decades to come under the name of Heavenly Mother, and then - from 1594 - St. John the Baptist; it was the place of residence, among others, the outstanding humanist and religious author Lismanin, and where his father Marco de la Torre delivered his lectures. According to Jakub Lichański - "apart from the royal court of Queen Bona, it was the second centre of the Italians living in Cracow." ${ }^{21}$

And indeed, after a certain time (a precise dating seems to be impossible), there was a confraternity founded at the chapel, that is the Italian fraternity officially called the "Confraternia di San Giovanni Battista della

20 Ibid., p. 85. A comprehensive biographic entry of Roncalli (T. Wasilewski, „Roncalli Domenico", in: Polski Stownik Biograficzny, vol. 32, 1 [no. 132], Cracow and Wrocław, 1989, pp. 10-12) reads: "An Italian by origin and upbringing" (ibid., p. 10), but it does not precise this information.

21 J.Z. Lichański, Łukasz Górnicki. Sarmacki Castiglione, Warsaw, 1998, p. 28. 
Nazione Italiana." It was a typical association of community character which - apart from religious purposes - aimed at the integration of the Italians living in Cracow and their mutual assistance. Their spiritual guardian was, according to the statute, was always one of Franciscan friars, speaking Italian and called "corrector". The main services attended by the Italians were on the days of St. John (24 June) and of the Madonna of Loreto (10 December). ${ }^{22}$

We cannot say whether the Cracow Italians universally entered into the association, and thus to what extent it was representative of the whole Italian community. Apparently, the outstanding Italian painter Tommaso Dolabella avoided his compatriots and did not belong to the confraternity but his attitude was regarded as eccentricity, so it could not have been universal. It is known, however, that some of the members of the Italian colony founded elements of the furnishing and equipment of the chapel, for example merchant Giulio del Pace, who in his will, prepared in 1608, bequeathed 25 Polish zlotys for the purchase of a painting. Del Pace was not the only one. The Commercial Register of the Italian Merchant of 1650 (Regestr handlowy kupca Wtocha z 1650), found recently by Feliks Kiryk in the collections of the Baworowscy Library in Lvov, was an Italian-language commercial book of merchant Tommaso Bellami, and contains valuable data about the institution we are interested in and donations for it. ${ }^{23}$

Bellami himself - by his last will and testament of 8 April 1644 wished to be buried in the brotherhood chapel of "Saint John the Baptist of the Italian nation," and in return endowed one thousand Polish zlotys to it. It was a big sum, but how numerous was the group which identified themselves with the confraternity, regarded it as their own institution and to such extent as to take care of its future in their last wills?

It is very difficult to answer this question. The list of members of the Italian Confraternity of 12 February 1640, published by Kiryk, included 28 names. The majority of those people are known to historians who are able to assess the group as materially and professionally diversified. ${ }^{24}$

22 Facts about the history of the confraternity are after: J. Muczkowski, Kościót sw. Franciszka w Krakowie, Cracow, 1901, pp. 26-27; S. Tomkowicz, 'Kupcy Wtosi w Krakowie, Rocznik Krakowski, 3, 1900, p. 11.

23 F. Kiryk, 'Przyczynek do historii Włochów w Krakowie', in: Polska, Prusy, Ruś. Rozprawy ofiarowane prof. $z w$. dr. hab. Janowi Powierskiemu, ed. by B. Śliwiński, Gdańsk, 1995 , pp. 85-88.

24 Ibid., pp. 88-89. 
Unfortunately, it appears that it is only the list of the members present at the meeting of that day, and not the list of the confraternity members. It seems even more impossible to determine the relationship between this group and the number and structure of the Italian colony in Cracow. We can only say that the colony had some very wealthy and influential members, such as Guglielmo Orsetti, Girolamo Pinocci or Rudolfo Cortino (Kortini). As long as people of this rank identified themselves with the confraternity as their community institution, its existence and prosperity were secured.

The most important Italian institution in Cracow, supplied by donations and bequeaths, could thus function in a very representative interior. The chapel - "decorated with exquisite stuccoworks and pictures" - had in its altar a marble sculpture presenting the baptism of Jesus in the Jordan River, allegedly by Baldassarre Fontana; the beautiful doors leading to the sanctuary were founded by a Cracow townsman Simone Muti. Even though he was from France, in his will he wanted to be buried in the Italian chapel, and bequeathed to the confraternity, among other things, a townhouse in Grodzka Street as well as numerous and valuable mobilia. The example of Muti, and also of pharmacist from Germany Walenty Pfail, another donator (both are listed in the Commercial Register), evidences a broadening of the group membership in the $17^{\text {th }}$ century to include also people of other nationalities, thus, the growing appeal of this institution which, in turn, contributed to the increasing prestige of the whole community.

The period of prosperity ended probably with the end of the $17^{\text {th }}$ century. In 1684 the Chapel was visited by the Venetian ambassador to Poland Morosini, received with great honours, but already in 1702, when Cracow was seized by the troops of King Charles XII the confraternity suffered severe material losses: its jewels and valuables together with ecclesiastical apparatuses were in their large part stolen or put for sale - because of huge contribution of 5,000 timpfs for the Swedish troops. It seems that throughout the $18^{\text {th }}$ century the confraternity was unable to regain its former position, and in time it lost also its Italian character which was evidenced, among other things, by the change of the language into Polish in official documents.

Its members displayed certain activity as late as during the Four-Years Sejm, and then with the rest of their valuables they supported Kościuszko's Insurrection; having lost all its wealth, the confraternity left its former seat and moved into the St. Barbara church. 
Of similar organisational structure were, as it seems, the associations of the Italians in Lvov and Lublin. Whereas to the most famous in Europe organisations of Italian craftsmen belonged the Italian congregation in Prague established in 1575, the Congregazione di Santa Maria Vergine - of the Blessed Virgin Mary of the Assumption, with its own chapel of 1590-1597 at the Jesuit church in the area of the Old Town, and a hospital existing from 1602 in the Mala Strana district. ${ }^{25}$

\section{Conflicts}

There was, however, the other side of the coin. Writing in the Polish Biographic Dictionary a biographic entry of the Lvov builder from Italy Piotr Krasowski, Adam Małkiewicz suggested that he could be identified with a certain Piotr called Niezgoda ("Petrus Italus Niezgoda dictus") who had already appeared in the literature on the subject (Łucja Charewiczowa). Not going into this identification, I would like to notice this nickname - so much meaningful in the context of this phenomenon of conflicts within the Italian community we are interested in.

Settling in a new place and building a successful business could and in fact did lead to conflicts with the environment. It is understandable, not to say natural. The only problem is the number and scale of these conflicts, their ratio to the state of harmonious coexistence. Conflicts of a financial character are to be found in court records, especially municipal, and their reader gains the impression that there were a lot of them. But this type of sources as a rule does not include peaceful situations but focuses on claims and resentments. The most important role must have been played by a commercial rivalry, and also - possibly - a competition in the market for commissions and contracts. There was also a rivalry for positions and status in the entourage of the king and at courts of the most influential dignitaries. We know, for example, that in 1669 Geronimo Pinocci competed with Lodovico Fantoni for the position of "Italian secretary" to King Michał Korybut Wiśniowiecki; I have already written above about the rivalry between Francesco Bibboni and Angelo Incontri for the post of resident of the Polish king in Madrit. There were certainly many more cases of this kind, but this was the sphere of conflicts limited to the narrow world of politics and diplomacy.

The most obvious form of rivalry within the Italian community was a competition of merchants operating in the same market and offering

25 J.A. Chrościcki, 'Kamieniarze i mafiosi. Zarobkowa emigracja z Włoch do Europy Środkowej i Wschodniej (XV-XVIII w.)', Przeglad Humanistyczny, 40, 1996, 1, p. 77. 
similar goods. A post office entrepreneur operating in Lvov, Roberto Bandinelli, supplemented his income by running a big store with Italian silk cloth. He was quite successful in this filed until 1635, when the city - under a separate contract - permitted his competitor, a certain Giulio Attavanti, to establish a big store of silk cloth, and granted him exceptionally good conditions and special privileges. Not going into the genesis of decision of the contemporary municipal authorities, we can repeat the words of Władysław Łoziński that Bandinelli was unable to stand up to such competition for a long time and had to give up his profession of silk merchant. It is known that he raised grievances against that state of affairs to the municipal authorities, and we can only guess at his attitude towards his go-ahead and suspiciously effective rival. ${ }^{26}$

An extremely important indication in the context of our reflections is to be found in diplomatic letters. The Tuscan resident, quoted already several times Niccolò Siri, in his letters written fairly regularly to Giovanni Battista Gondi, did not limit himself to stricte political subjects. In December of 1643, when he informed about his planned trip to Lublin because of the session of the Crown Tribunal, he also suggested that it was a good opportunity to think about commercial interests in that neighbourhood. ${ }^{27} \mathrm{He}$ asked Gondi to present some suggestions to the grand duke of Tuscany and to undertake efforts to strengthen the one-man representation of the Grand Duchy of Tuscany in Poland. The above suggestion should be examined very urgently for - according to its author - at this very time the Florentines suffered some heavy losses in the markets of the Commonwealth from where they were squeezed out by merchants from Lucca and Venice, the negative consequences of which were already evident in the Florentine market. ${ }^{28}$ Siri proved to be a Tuscan patriot who the threat to the group he identified with saw in the activities of Italian merchants from other rivalling centres.

It stands to reason that a strong competition with resulting animosities and conflicts was between artists - especially architects and builders. The sudden death of Bartolomeo Berrecci, killed in 1537 in Cracow market square, but also the murder of his son Sebastiano in 1546 in unexplained

26 Łoziński, Patrycyat i mieszczaństwo lwowskie, p. 181.

27 “[...] fare in questo paese qualche negozietto", Siri, Lettere da Cracovia, p. 114.

28 "[...] potessi avere qualche appoggio con metter qua in mia compagnia chi paressi a Vostra Signoria Illustrissima, e massimo oggi che la nazione fiorentina in queste parti ha perso assai, essendoci tutti luchesi e veneziani che è di danno alla piazza di Fiorenza molti migliaia di ducati all'anno", ibid. 
circumstances could be regarded as the extreme examples and at the same time as evidence of that competition. In the case of Bartolomeo it is sure that the perpetrator of the crime was of Italian origin ("treacherously murdered by a certain Italian for jealousy"), and in the case of Sebastiano it is highly probable. ${ }^{29}$ There is a presumption that came close to the truth that those conflicts stemmed from the competition in the labour market, already dominated by Italian immigrants ready to realise next architectural and building commissions.

Some time later, in 1561, builder Tommaso da Robore was killed, who together with his brother Alessandro was to vault the side naves of the St. Catherine church in Cracow. The fact that his main rival was a certain Antonio Morassi who finally took over the work makes us guess at possible motives and the course of event. ${ }^{30}$ These cases, however, were as much spectacular as isolated; but they can testify indirectly to the existing at that time tensions and rivalries between the Italians who tried to settle in Cracow.

Juliusz Chrościcki, whose studies I have been used here, has tendencies to emphasise antagonisms between Italian constructors. He says that they associated in building groups, often identical with the family clans who divided the territory of the country between themselves and did not allow any competition. This raises the suggestion that we deal here with a mafia system, or rather mafia-clientary system. This interesting proposal seems not to take into account the existence, especially in the field of architecture and building trade, of great demand for Italian services and the fact that this demand seemed to be constant at least until the end of the $17^{\text {th }}$ century. This must have considerably weakened market competition between contractors. Whereas the spread of the clan structure over the extensive territory of the Commonwealth would mean the unquestionable excess of supply over demand for building and investment services which would a the fact of paramount importance. Let us add that Juliusz A. Chrościcki is not alone in his attempts to reconstruct the clan system in reference to Italian artists and contractors. While analysing quite recently the mechanism of career development of architect Tommaso Poncino, Mariusz Karpowicz said that "the puzzling career of master Tommaso in our country was not accidental, but

29 See: M. and S. Cercha, Pomniki Krakowa, pp. 170-171; after: Chrościcki, Kamieniarze $i$ mafiosi, p. 77, with a comprehensible list of literature on the subject. 30 See: Chrościcki, Kamieniarze i mafiosi, pp. 77-78. 
resulted from the combination of his own enterprise with the tacit or explicit support of the clan." 31

Thus, the internal cohesion of the Italian colony, as the Italian community of Cracow was occasionally called, or the Italian minority in the Commonwealth, as this whole diverse national group should be called, is very difficult to assess unambiguously. There occurred at the same time tendencies and processes of integration and disintegration. But even with all that political and cultural diversity of the Italian Peninsula and different interests of the Italians in the Commonwealth, the tendency to integration, mutual help and solidarity in their new environment seems to have gradually, but steadily gained dominance.

Relations with a new environment - the ease of adaptation

\section{What and who did they find?}

When analysing the question of life strategies of the Italians coming to Poland, a question arises about possibilities in this country which would determine and limit the chances of individuals and particular professional groups. Not less important seems to be the question whether that reality did change with time and what was its evolution.

An assessment of the reality existing in Poland by the Italians coming to Poland, that is the answer to the question what and who did they find here is very important to our reflections. But answer formulated on such a level of generality could not be precise. Much depended on an individual situation that determined the process of possible adaptation and its pace. It was different for an Italian invited to the royal court or the court of some magnate, and different for someone who came to Poland to join a group of resident Italians and was taking up business activity within the structure of merchants, bankers or craftsmen, and also different for people who had to blaze the way and go into the unknown, with only some general information about a new place. Still different was the situation of persons who, by definition, were functioning within an organised structure and it was in such a character - that is "on business" - that they were arriving in Poland, for example members of religious communities, nuncios, and also secular diplomats. In those cases the level of risk was far less and in fact it was limited to hazards of journey only.

31 M. Karpowicz, Tomasz Poncino (ok. 1590-1659) - architekt Patacu Kieleckiego, Kielce, 2002, p. 11. 
Accepting the fact that the phenomenon we are interested in is very individualised and thus diverse, and that it was characterised by casualness, we would nevertheless like to pose a question about the existence of possible circumstances favourable for a social fusion or only Polish-Italian coexistence at the territory of the Commonwealth. Assuming that the incentives which made the Italians migrate did not determine its destination, we have to ask whether there were any qualities which would made the Polish-Lithuanian state especially attractive in this regard.

Firstly, this is the question of the nature of its inhabitants. Historians have been interested in this extremely broad subject for many years, and yet there are still no unambiguous conclusions and probably they are impossible to formulate. It is worth to look at some possibilities and ways of argumentation.

"From all nations of Transalpine Europe Poles are probably the best" - wrote in his interesting relation of 1565 Fulvio Ruggieri, often quoted in this context, the papal diplomat or, to be more precise, secretary of the outstanding nuncio Giovanni Francesco Commendone - "namely the noblemen are polite, courteous and, as it has been said, hospitable. Albeit they are clever, they do not enter inter a deeper cognition of things, they more easily learn what has been already discovered than what they have to discover by themselves in sciences or arts, and they do not seek perfection in anything, maybe because they are committed too much to a comfortable and merry way, because they are too busy with military affairs and agriculture, or because they are too prone to barratry and they like to pull strings for their friends." 32

Is it not a vision of a noble nation, which perfectly meets the needs of people who would like to surface in a new environment? Politeness and hospitability, combined with an intellectual superficiality and clearly defined spheres of interest which were never exceeded; together with informal bonds, ordering mutual relations within the estate. Let us add that in formulating this characteristic, Ruggieri, like many other outside observers, was almost certain to have made use of opinions by Polish authors (such as Maciej of Miechów, and especially Marcin Kromer), who in the $16^{\text {th }}$ century wrote their compendia for the foreign readers. Thus this image encouraging possible contacts was substantially of the Polish origin.

32 Relacye nuncyuszów apostolskich i innych osób o Polsce, od roku 1548 do 1690, ed. by E. Rykaczewski, Berlin and Poznań, 1864, vol. 1, p. 127. 
If we are to believe Marcin Kromer and his numerous successors who in the $16^{\text {th }}$, and also in the $17^{\text {th }}$ century wrote the characteristics of the Polish nation (in general, with the foreign readers in mind), an important element of this image was hospitability (which is still described as the "old-Polish") and curiosity about the world. Naturally, these were factors conducive to an initial acceptance of foreigners. There is, however, another important element in Kromer's picture, which was not exposed by Ruggieri; it was the emphasis put on a Polish simple-heartedness which in the author intention is a positive trait, although in fact it came close to both simplicity and gullibility. This simple-heartedness, combined with a trust, turns out to be very important when together with hospitality. And if we add another remark, made by a foreign observer, the anonymous author of a broad account of Poland written in English in 1598, that "In negotiating by suite the Poles must be handeled with greate dexterity [...]. They must be smoothed cunningly (and though apertly, it is no matter) with titles, and commendations, muche attributed to the states, and in generali all pleasant baites used for theire humoure."33

As if that was not enough, the quoted $A$ Relation of the State of Polonia associates expressis verbis the phenomenon of mass arrival of the Italians to the Commonwealth with national traits of Poles. At the beginning of this long text, after the etymological explanations, there is a characteristic of those "Poloni" who compared to other nations were friendly, polite, sensible to the delights of the table, bright, tolerant and did not attach too much importance to material matters. "Theire nature being suche - wrote the Anonym in 1598 - and so well knowne to the Italians, hath drawne greate nombers of them into Polonia [...]." ${ }^{34}$ Thus, it was those features of Poles which attracted the Italians, as if being a collective invitation!

In a discussion about the authorship of $A$ Relation of the State of Polonia no explicit conclusion was reached. It is attributed to one of two persons, known by name: the Scotsman, William Bruce, who spent many years in the milieu of Chancellor Jan Zamoyski and was a professor at the Zamoyski Academy; and the outstanding English diplomat, Sir George Carew, who in 1598 was sent with a diplomatic mission to Poland, and is even more known as the author of his later account about France

33 [Anonymous, 1598], A Relation of the State of Polonia and the United Provinces of that Crown, Anno 1598, ed. by C.H. Talbot, Rome, 1965 (Elementa ad fontium editiones, 13), p. 136.

34 Ibid., p. 3. 
(A Relation of the State of France). It is also probable that the text was written by both these people together or that its author was someone else, albeit from the environment of one of them. ${ }^{35}$ The establishment of this fact would be important to us, for the authorship of Bruce would mean much greater contribution of the Polish milieu to the formulation of the above opinions, while in Carew's case this influence would be much less obvious, and his relation would have more outside, foreign character (which does not exclude a coexistence in this Relation of contents and opinions of a very different provenance).

If, however, a vital outline of the above characteristics of the Polish nation (or the noble nation?) we regard as true, we will be easily able to imagine an impulsive, garrulous Italian, interesting to an inhabitant of the Polish-Lithuanian Commonwealth because of his exotic origins, and in addition paying compliments which successfully created a favourable attitude toward himself. It could have been this way. I am therefore inclined to think that in the sphere of national character (with all reservations towards this notion and its generalisations) there were weighty factors generating a harmonious coexistence of the Italian immigrants and Polish hosts. ${ }^{36}$

As a matter of fact, this conclusion is similar to Ettore Lo Gatto's thesis who writting in Mussolini's time and subordinating his reflections to a fundamental - launched by the fascist ideology - thesis about the grandeur of Italian nation and strong impact of its ancient culture indicated a perennial inclination of the Salvs to Italy and the Italians.

The conclusive argument of this otherwise outstanding erudite writer was that the Slavs were learning Italian for mere pleasure, while they study French, German and English for practical matters. ${ }^{37}$ Thus, the conclusion was similar, but the reasoning - let us hope - was quite different.

35 A. Mączak, Klientela. Nieformalne systemy wtadzy $w$ Polsce i Europie XVI-XVII w., Warsaw, 2000, p. 150, where is a summary of that discussion together with a conclusion that it was probably "Carew or a member of his legation who was helped by Bruce and on the basis of his information compiled this compendium of the knowledge of Poland." 36 “[... nie masz kraju, wyjąwszy naszą Polskę, gdzie by ludzkość i gościnność była znajomsza, jak w kraju włoskim" ([...] there is no country, except for Poland, where people and hospitability were more familiar than in the Italian country") wrote in 1787 Grzegorz Piramowicz, polemicising with the image of Italy presented by the quoted above Pamiętnik Historyczno-Polityczny, see: Libera, 'Obraz Włoch', p. 231.

37 E. Lo Gatto, Civiltà italiana nel mondo: in Boemia, Moravia e Slovacchia, Rome, 1939, p. 8. 
The second equally important issue which requires at least to be signalled in the context of Italian possibilities for adaptation is the question of organisation of social life, relations between the estates, the ways of functioning of the state and its institutions. This will be the subject of a broader analysis presented in a separate essay; here I would like to formulate a few of preliminary hypotheses only.

Were the structures and institutions of the Polish-Lithuanian state easy to infiltrate by foreigners or were there barriers which hampered this infiltration or made it quite impossible? This is another important question which we are unable to answer unambiguously.

On the one hand, both the social structure and the state structures were clearly different, which seems to be obvious after we compare the Italian city republics and their relative small but densely populated territories with an extensive and incomparably less populated territory of the Polish-Lithuanian Commonwealth. What could have been surprising for the Italian immigrants was the social structure, with the very clear-cut social estates, and the domination of the nobility, blocking the growth of wealth of the burghers. Also the peculiar separation between the worlds of the nobility and of the townsmen (not to mention the peasantry) must have been different. The local distinction expressed itself also in specific relations between the town and the country: important and rich people lived in the country and only sporadically visited neighbouring towns, and in any case, they did not coexist with their inhabitants on a daily basis, like in the Italian Peninsula, where in the capital cities the distance between the estates was perforce reduced. Here, on the Vistula River, the prestige and richness were much more decentralised, and at the same time the fact of being a capital city had quite a different dimension and was much less important. Because in the Commonwealth the relations between the centre and peripheries were very specific, and this is an element which has recently been recognised as very important for the functioning of a early modern state: in this case the peripheries seemed to dominate the centre, or centres, for there were at least a few of them.

At the same time the Commonwealth could have made a very good impression on immigrants from a distant country, even if only by its expensive areas and ample space, not only in the geographical sense of the word (which is indisputable) but also in the social one. Because I do not mind a relatively low population density related to the expanse of its territory, but a bit backward structure of relations between particular 
segments of the society in which there was - for this very reason - probably a lot of place for both people from outside and the innovations they were bringing with them (in this way a great success of the settlement with German law in the $13^{\text {th }}$ century has been explained). In addition, the power - of the state, the public one - was weak, and the state itself and its institutions were quite rickety. And in any case, it was oriented to protect interests of the nobility, while the estate of burghers (and to some extent also the lower clergy) had to regulate possible disputes and obedience of law on their own. This resulted in tolerant attitudes which were so willingly adopted by the noble hegemon, provided that its privileged position was not threatened. It was this type of tolerance that the Italian newcomers could have counted on, if the above condition was met, which was not difficult for them.

It is probably worth to reflect on a general condition of the state and old Polish society - in the context of the Italian immigration. Treating the subject in a schematic way, we can formulate a question whether it was easier for the Italians to adapt themselves and then make their stay materially and socially rewarding in a relatively rich and stable country (or at least in a stage of economic growth), or in a state which was descending into crisis and anarchy?

The answer is not an easy one. On the one hand, if a country of wealthy citizen $s^{38}$ accepts foreigners at all, it also offers them access to its wealth, at least becoming their commercial partner willing to buy their products. A wealthy country and free of major internal conflicts should offer more possibilities to immigrants, at least in a material sphere, since in a social and political sphere the stable system could prove to be closed and difficult to penetrate from outside. On the other hand, a growing crisis, both of the economy and social and political structures, can open a broad field for the activities of intelligent people who know how to profit from this instability.

In this way, we imagine the evolution of the situation of Italians in early modern Poland. The relatively wealthy and affluent Poland in its Golden Age was a willing buyer of commodities and services offered by the Italians, since they were used by a large part of the noble estate and

38 Due to a schematism of this reasoning I will not repeat rudiments - that the term of wealthy citizens includes only the nobility, from the middle one up, and also the wealthiest elite of the burgers, and that the state structures of the Commonwealth were far from being perfect. 
even by a narrow elite of the burghers. The worsening social economic conditions of the Commonwealth in the centuries to follow drastically limited these possibilities. But the Italians do not resign (obviously, the factors inducing them to leave their country do not vanish, or maybe they become even more nagging). Thus, they turn to the magnate elite of the noble estate, and at the same time - having acquired the necessary knowledge about the Polish-Lithuanian reality - try to adapt to it and take advantage of its perceived weakness. In such a way we can see their political and diplomatic activity (attempts to influence the elections), and above all - the banking services they offered and leasing of mints.

Regardless of the attitude dominating among the Italian migrants, if we talk about the nature of their stay in Poland (from immediate financial benefits to decisions about permanent emigration), it would be only right to ask about the objective conditions and possibilities for adaptation in which immigrants found themselves in the new land. In Sebastian Gawrecki's known travel diary we find a colourful although a bit roughly sketched figure of innkeeper, the owner of an inn called Under the Golden Cross, near Montmelian in French Savoy. This is a fragment of a concise description which I quote in its original form: "Gospodarz włoch ma lat 89 rzyźwy jakoby we 30 lat drugi [...] miał żon 4, teraz z czwartą jeszcze mieszka, z któremi był zpłodził potomstwa 28, ale wszystkie pomarli, tylko co 6 zostało żywych. Mieszka w tem miasteczku lat 60 , kędy po francuzku mówią prawie wszyscy, a on się dotychczas nic nie nauczył po francuzku, po włosku się rad sprawuje [...]." 39

Maybe this vigorous old man turned out to be extremely resistant to the influence of the alien or at least foreign-speaking environment, maybe it was his profession which induced him to preserve, or even to emphasise that he was different, while at the same time - as it follows from the quoted fragment - he did not avoid contacts with the local people. Let us regard the observations of our peregrinators (Gawarecki was the guardian of the young sons of Voivode Kryski and he travelled with them) as a subtle suggestion, a testimony of the Italian immunity to foreign influences and their attachment to their native language in

39 S. Gawarecki, 'Droga do Francyjej, do Paryża', in: Pisma do wieku i spraw Jana Sobieskiego, ed. by F. Kluczycki, vol. 2, Part 1, Cracow, 1880, p. 125 (The host, an italian, is 89 and vigorous like a thirty-year-old man [...] he had four wives, now he lives with the fourth one, with whom he had begot 28 children, although all are dead but six. He has lived in this town for sixty years, where almost all speak French, but he has not learned French and is glad to stay with Italian). 
a culturally different reality. Even though it is a separate example, it is worth thinking about, for we deal here with the Italian-French borderland and for this reason the environment of the Italian innkeeper (even considering the different language) was certainly very similar to the reality of his homeland.

What adaptation difficulties could encounter the Italians in Poland and what they had to deal with? Among the obvious one there was a whole array of geographic and cultural differences, starting with the climate realities of transalpine Europe, and in its more severe, eastern version, and ending with the nature of the society and feudal-estate social structure the adaptation to which required both their will and ability.

The barriers included also the language, although it was a novum and possible difficulty which each immigrant has to take into account. Here, a question could be posed whether this barrier in the Polish-Italian relations was a big one? A negative answer, which I am willing to instinctively give, could prove to be hasty, for we cannot be deceived by modern, often overoptimistic opinions about the possibilities of communication between the Poles and Italians. A relative ease with which Poles learn Italian and relatively quickly absorb the rudiments of the language (which, in any case, turns out to be illusory when one wants to seriously treat the study of the language!), was not shared by the Italians wanting to learn Polish (although there are some cases of outstanding perfection in this matter). The Polish language enjoys the fame of being difficult for foreigners and we are not justified in thinking that it was different four centuries ago. The only argument which would indicate otherwise is a semantic similarity between Polish and Latin and a much more common knowledge of the latter in early modern Europe than today. It does not seem, however, to be a conclusive argument.

Thus, in the case of early modern immigrants, also Italian ones, this barrier certainly existed, as evidenced by extremely interesting, albeit occasionally surprising remarks made by Friedrich Schulz, a Livonian travelling across Poland at the end of the $18^{\text {th }}$ century. When characterising a specific and difficult pronunciation of many Polish words (too many consonants), a predilection of Poles to speak quickly and their tendency to shorten long words, Schulz argued that it required the "agility of vocal organs," and this could be acquired only when "practiced since childhood." And for this reason - as this perspicacious observer continued - "after fifty years in Poland a foreigner will be always given 
away by its pronunciation that he was not born in this country." ${ }^{40}$ And for this reason I am inclined to accept without any reservations this important remark showing that it was very difficult to fully mingle with the Polish environment.

What is surprising is some of other comments by our Livonian about the difficulties with the Polish language of members of the most important nationalities living in the contemporary Commonwealth. Even German settlers, who were born and brought up here, "could be recognised by their more heavy, slow speaking"; comparing with Germans, "it is more easy for Frenchmen to speak good Polish, they could be given away only by their nasal tones." Next, there are listed Italians in whom we are most interested here; and here we have another surprise: it is much more difficult for them to learn Polish, because their language, like German, "has a slower pace." Surprised that the Italians had difficulties in keeping pace with the speed of the Polish language and that the nature of their language was close to that of Germans, we are not astonished to learn that Englishmen had the least chances of learning Polish. And he repeated his previous generalisation, that the "nation whose tongue is the quickest has the best chances to learn Polish."

Quoting loyally Schulz's opinions, I would like to distance myself a bit from them because, among other things, they were formulated by the end of the $18^{\text {th }}$ century, thus after the period of the Saxon rule in Poland and in the times of unquestioned domination of French culture in Europe. Both these phenomena could have influenced contemporary ideas about similarities and differences between main national languages and change the hierarchy of their knowledge in Poland.

It is, however, impossible to accept a thesis that the language barrier, which objectively has always existed, was especially difficult for the Italians, especially if we apply it to the $16^{\text {th }}$ and $17^{\text {th }}$ century. At that time, the Italian language was present in Polish, and Polish elites had frequent contacts with its original version - both during their studies in Italy and contacts with the Italians in Poland.

There is still one problem left for us to be discussed: the problem of conflicts between Italian immigrants and the local environment. I will treat this subject in a perfunctory manner, citing only a few examples

40 F. Schulz, 'Podróże Inflantczyka z Rygi do Warszawy i po Polsce w latach 1791-1793', transl. by J.I. Kraszewski, in: Polska stanistawowska w oczach cudzoziemców, ed. by W. Zawadzki, Warsaw, 1963, vol. 2, p. 613. 
to illustrate the types of possible conflicts - in the sphere of politics, commerce and broadly understood contracting and enterprising - and formulating a conclusion which in fact is positive for the Polish-Italian relations.

In 1533 there was a fight at the royal court between Hieronim Lanckoroński, Fabian Czerna and Mateusz Podolski, on the one side, and the Italians Annibale Bentivoglio and Carlo Marchesini on the other. The fight was caused by excessive favours conferred by Queen Bona on the Italian courtiers. ${ }^{41}$ This is the first category of conflicts. Polemical literature, especially this of the $17^{\text {th }}$ century, is replete with statements against the foreigners at the royal court who were accused of throwing their weight around and giving bad advice to the king; some of those accusations were of anti-Italian and anti-papal character; some, formulated in the second half of the $17^{\text {th }}$ century, were against minting activities of Tito Livio Burattini, who - as a leaseholder of the state mints - was accused of very serious financial embezzlements (it was never proved). It is difficult to ignore those voices, especially that in the following decades of the $17^{\text {th }}$ century they were becoming more and more loud, but it should be also remembered that they were mainly of political and propagandist character.

In 1574 a guild of cloth makers from Cracow accused sculptor Geronimo Canavesi of illegal trading in cloth or, to be more precise, of not paying due fees to the municipal treasury. ${ }^{42}$ It should be explained here that Canavesi began his activity in Poland as court sculptor - thus he was a servitor, that is a person exempted from the jurisdiction of municipal law; only after staying a dozen or so years he acquired the citizenship of Cracow (1573), to function within the guild structure soon afterwards. Evidently, this change in his social standing resulted in a conflict, or the conflict - kept hidden before - came to light at that time. Indeed, it was the very institution of servitorate which gave rise to conflicts, since it made it possible for Italian artists and contractors to operate independently from municipal laws, which surely was not liked by the rest of the burghers, especially by craftsmen belonging to guilds, and thus subjected to guild regulations and restrictions. Support of the royal court could also result in various privileges and concessions in their commercial activity, which

41 S. Cynarski, Dzieje rodu Lanckorońskich z Brzezia, Warsaw, 1996, p. 125, with a full documentation of sources for this incident.

42 Ptaśnik, 'Z dziejów kultury', p. 107. 
had to be against interests of local merchants (another thing is to what extent individual decisions were executable). For example, under King Bathory a certain merchant and member of the Cracow council, Battista Fontanini, was granted a special right to sell foreign cloth, mainly from Italy - as it could be read in a relevant document. ${ }^{43}$

Yet, a fundamental axis of possible conflicts was determined by the relations between the person who commissioned service and who delivers this service. Here, the field for mutual pretensions was broad, starting with negotiations for the price of a bought commodity and value of offered services or working conditions, and ending with the quality of performed services or supplied goods. This, however, is the question of subjective opinions and individual reactions; in a mass scale the opinion must have been positive, since throughout the $16^{\text {th }}$ and $17^{\text {th }}$ century Italian involvement in Poland certainly possessed traits of permanence.

Nonetheless, there were some evident slip ups and blunders in the quality of services performed by the Italians. Matteo Castello, as we know, took over the responsibility for constructing of the Cracow church of Saints Peter and Paul after a building catastrophe under his predecessor Giovanni Trevano. Some time earlier dramatic ordeals were experienced by Piotr Krasowski, an Italian builder operation in Lvov in the second half of the $16^{\text {th }}$ century, who from 1568 supervised the prestigious construction of a tower at the Wallachian Orthodox church building. In 1570 the tower, brought to a "third scaffolding", collapsed, and its founder brought a lawsuit against the unfortunate constructor. Interestingly, this spectacular professional failure did not stop - at least in a short time - next commissions, but I notice this case since it illustrates the whole sphere of relations between the patron and contractor, when the first one was not satisfied with the quality of performed services.

Other type of conflicts, a bit specific one, were erupting - which has been recently reminded by Juliusz Chrościcki - in monastic construction sites. Jesuit architects (like, for instance, Giuseppe Brizio in Poland already from 1575, the much more known constructor of the church at Nesvizh Giovanni Maria Bernardoni or active from 1616 Giacomo Briano) did not want to do physical works when constructing buildings according

43 “[...] omnis generis pannorum exoticorum et peregrinorum maximo vero ex Italia, Venetia, Mediolano", Warsaw, Central Archives of Historical Records, Metryka Koronna (The Crown Register), 123, 1. 759; after: A. Mączak, Sukiennictwo wielkopolskie, XIV-XVII wiek, Warsaw, 1955, p. 230. What is worthy of note here is the lack of terminological consequence in the expression "ex Italia, Venetia, Mediolano." 
to their designs, which led to conflicts with their local authorities. ${ }^{44}$ But here the conflict proceeded within the monastic structures.

It seems that Juliusz Chrościcki was too strict when in his other, very interesting article with a provocative title Stonemasons and Mafiosi he wrote: "I could present here a long chronicle of building catastrophes caused by Italian craftsmen or their proverbial failure to meet deadlines, drinking and dirty tricks played on their local and Italian partners. But I have been helped out by other researchers." ${ }^{45}$ These "other researchers" are Bolesław Przybyszewski, who presented a conflict between Cracow canon Andrzej Zebrzydowski and Italian masons, Helena Kozakiewiczowa - investigating the activity of an architectural sculptural company of Bernardino de Gianotis and Giovanni Cini, and Robert Kunkel, who analysed enterprises of that Bernardino de Gianotis in Płock.

Not polemicising with the facts established by outstanding art historians, I take the position that those were isolated incidents that could not have been totally avoided with this scale of architectural and construction works. For a possible conflict between the investor and contractor is in a sense inscribed into their mutual relations. And the conflict - at it has been already said in reference to the relations between the Italians - by its nature generates historical sources. Mutual pretensions and claims had to be formulated in writings, and occasionally conflicts were resolved by the competent courts which in turn adhered to their procedures and had documentation. On the other hand, the documentation of relations without conflicts is much more scarce, which brings about the danger of distorting the image and proportions.

Surely, a majority of Italian achievements, especially in the field of architecture and engineering, must have been valued and accepted, if all the time there were in the Polish-Lithuanian market new commissions and orders. Here we have yet another example of service, the quality of which could be difficult to question.

Ending his detailed letter to Ismaele Boulliau, written in Warsaw on 7 October 1672, Tito Livio Burattini described one of such unquestionable achievements. It was a structure constructed by a certain colonel Fridiani,

44 J.A. Chrościcki, „Rola włoskich projektantów i rzemieślników w przemianach sztuki barokowej (Europa Środkowo-Wschodnia)", in Barok w Polsce i w Europie Środkowo-Wschodniej. Drogi przemian i osmoza kultur, Warsaw, 2000, p. 190.

45 Idem, Kamieniarze i mafiosi..., op. cit., p. 77. 
active at that time in Vilnius. ${ }^{46}$ The colonel must have been well-known to the addressee from the time of Boulliau's visit to Poland and their common stay at Jazdów; this expert in artillery was promoted to the officer rank in the Grand Duchy of Lithuania, where he was granted - as we read - a substantial salary. So, Fridiani during his visit to Vilnius last year was supposed to have been offered by the municipal authorities a proposal to build a solid - "for one hundred years and more" - bridge across the Vilnia River, described by Burattini as "briskly flowing and deep, with high banks, and wide for 400 feet." ${ }^{27} \mathrm{~A}$ former wooden bridge was every year destroyed and taken away by a spring freshet and ice jam, and to rebuild it cost ca. 50,000 florins each time.

After short negotiations a contract was drawn and necessary materials supplied. Frediani constructed a bridge - we have to appreciate his engineering art - based on an arch, without pilings driven into the riverbed. The structure had an impressive elegance, since it was made of stone panels and the whole of it was covered by a roof ("per essere lastricato di pietra e tutto coperto"), and also because it was very long ("smisurata longhezza"). It could only be regretted -Burattini wrote - "that this structure has not been constructed in some other town whose inhabitants would be able to appreciate the engineering art of the designer ("siano huomini ingegnosi che possano ammirare l'ingegno dell'inventore").

Having swallowed this bitter pile, not nice for the inhabitants of Vilnius (and maybe the whole Commonwealth), let us add that Burattini complimented also the costs of the investment which - borne once - proved to be lower than an annual reconstruction of the structure (the construction cost 25-30,000 florins, and each reconstruction 45-50,000), and, which in this context I regard as the most important, suggested to create and duplicate in print a sketch of the analysed bridge to distribute throughout the world (evidently for advertising and promotional purposes, as we would say today), for such a solution had been never seen before. ${ }^{48}$

Bearing in mind that the above compliments were uttered by the Italian and were about another Italian, we can assume that we are sure to

46 "Concluderò questa mia lunga lettera - Burattini wrote - con darli notitia d"una machina che fa in Vilna il sig.re Colonello Fridiani”, Favaro, op. cit., p. 128.

47 "[...] un fiume molto rapido e profondo che si chiama Wilia, il quale ha le sponde assai alte et è largo quattrocento piedi”, ibid.

48 "Io non credo che in tutto il mondo ve nè sia un simile d"un sol arco, ne che mai sia stato", ibid., pp. 128-29. 
deal here with a professional description, and probably an objective one, since neither the writer of the letter not its addressee was engaged into the matter. Thus, according to my opinion, a general questioning of the quality of services provided by Italians is both groundless and pointless.

Let us summarise: the arrival of foreigners, their permanent settlement, functioning at the royal court, deriving benefits from commerce and economic enterprises must have provoked conflicts and protects of the locals. In this context, a number of grievances was very moderate, especially in reference to Italian contracting and services. In sum, it seems that - although it is very difficult to compare with the situation in other countries - we can formulate a hypothesis that the Polish realities were favourable for the Italians. Apart of all what has been said here, they must have found some cultural similarities - based for example on mutual Latin roots and the common Catholic religion.

His chronicle of Ruthenian land (Kronika Ziemie Ruskiej), making up one part of his work entitled From the Chronicle of European Sarmacy ( $Z$ Kroniki Sarmacyi Europskiej), Alessandro Guagnini dedicated to Zygmunt Myszkowski. ${ }^{49}$ A text of the dedication by this Italian feeling at home in our country, with literary and chronicle ambitions and some measurable successes at this field, the dedication addressed to one of the most outstanding Polish Italophiles is worth to be quoted instead of conclusions. The text is dated in Cracow, 24 October 1611. Guagnini begins his discourse by saying that it is not a poor treat of the clever man to serve more to his homeland then other countries, and without difficulties finds ancient references for this thesis ("Acz nie pośledni znak jest człowieka mądrego, więcej ojczyźnie swojej, niż postronnym krajom służyć"). Then, he turns to a characteristic of his own attitude:

Ja jednak nie boję się tu żadnej nagany, choć obcy będąc, przywiążę się do zacnego narodu polskiego, jako do własnej ojczyzny. Albowiem, jeśliż każda ziemia (jako Sokrates mówi) dzielnemu mężowi ojczyzną jest, osobliwie ta, której się lepszą część wieku, z jakiemkolwiek nabyciem dobrego imienia odprawuje..$^{50^{*}}$

49 [Gwagnin], Z Kroniki Sarmacyi Europskiej, Alexandra Gwagnina z Werony, Opisanie Polski, W. Ks. Litewskiego, ziemie ruskiej, ziemie pruskiej, ziemie inflantskiej, ziemie $\dot{z} m u d z k i e j$, ed. by K.J. Turowski, Cracow, 1860, pp. 181-83; with a signature under the dedication: „Alexander Gwagninus, Comes Palatii Lateranen., Eques Auratus, militumque Praefectus."

$50{ }^{*}$ However, I do not fear any reprimand here, for although I am of alien origin, I became emotionally attached to the virtuous Polish nation as much as to my own homeland. Because, if every land (as Socrates says) is a homeland to the brave soldier, 
Without mentioning the rhetoric formulated in the spirit of peculiar internationalism, we deal here with a declaration of attachment of a foreigner to his new homeland, to which he dedicated a majority of his days. Thus, he made a key decision for his life which - as is evident from the next fragments - he does not regret:

[...] ja się między szczęśliwymi kładę, żem w onych leciech moich do Polski nieco wprawiony jest, i nie indziem dowcipu, rozumu, zabaw żołnierskich, i inszego uczciwego życia owoc położył. Albowiem choćbym się był między onemi staremi Rzymiany urodził, a tu potem między ten brak ludzi w każdej cnocie przedni udał, nigdybym był tego nie żałowat..$^{51^{*}}$

Thus, Gwagnin does not regret, on the contrary, he is fully satisfied with the effects of his decision of emigration, which he explains with great virtues of the inhabitants of the Commonwealth, including their piety together with war and peace virtues. And although the emphasised this time old-Polish attributes differ slightly from the vision promoted by Marcin Kromer (in the $17^{\text {th }}$ century it was the Polish piety which was exposed!?), it has no significant impact on the meaning of statement of the naturalised Italian. A long and, in fact, very productive Polish-Italian coexistence in the territory of the Commonwealth was made possible by compatible characteristics and - let us add - by a unique structure of the Polish-Lithuanian state, the structure which was so open and voluminous structure that the Italian immigrants were able to find a suitable space for themselves and their activities.

\section{Translated by Grażyna Waluga}

First published as: „Razem czy z osobna? Procesy integracji włoskich imigrantów w Rzeczypospolitej szlacheckiej”, Odrodzenie i Reformacja w Polsce, 48, 2004, pp. 7-35.

especially that which a better part of a century, with any acquisition of a good name, has been devoted.

51 * I lie down between happy people for this reason that I am somehow accustomed to Poland in these years and in no other place I have the fruit of my wit, reason, soldiery games and other emotional life placed here. For even if I had been born among these real Romans, and then faked here among this lack of people in each virtue, I would never regret it. 